\title{
ANALISIS FAKTOR-FAKTOR YANG MEMPENGARUHI KINERJA SISTEM INFORMASI AKUNTANSI PADA BANK RAKYAT INDONESIA KANTOR CABANG BENGKULU
}

\author{
Khaidir \\ Neri Susanti \\ Program Studi Akuntansi \\ Fakultas Ekonomi Universitas Dehasen Bengkulu
}

\begin{abstract}
ABSTRAK
Khaidir, Neri Susanti; Tujuan penelitian untuk mengetahui faktor-faktor yang mempengaruhi kinerja sistem informasi akuntansi pada Bank Rakyat Indonesia Kantor Cabang Bengkulu. Sampel dalam penelitian ini adalah karyawan Bank Rakyat Indonesia Kantor Cabang Bengkulu yang memakai atau menggunakan sistem informasi akuntansi sebanyak 42 orang karyawan. Metode pengumpulan data dilakukan dengan metode survey sedangkan analisis data menggunakan rating scale. Hasil penelitian diketahui bahwa faktor yang paling dominan mempengaruhi kinerja sistem informasi akuntansi pada Bank Rakyat Indonesia Kantor Cabang Bengkulu adalah faktor kepuasan pengguna akhir jumlah rata-rata sebesar 176, faktor kedua adalah program pendidikan dan pelatihan jumlah rata-rata sebesar 173 , faktor selanjutnya adalah dukungan manajemen puncak jumlah rata-rata sebesar 168 dan faktor terakhir adalah kemampuan teknik personal jumlah rata-rata sebesar 165. Disarankan kepada pihak bank perlu melakukan evaluasi terhadap sistem informasi akuntansi yang mereka gunakan agar sistem yang sudah mereka pakai selama ini dapat sesuai dengan kebutuhan dan tuntutan kondisi perusahaan.
\end{abstract}

\begin{abstract}
Khaidir, Neri Susanti; The research objective to factors determine the performance of accounting information systems at Bank Rakyat Indonesia Branch Office of Bengkulu. This study is a descriptive study, with a sample are employees of Bank Rakyat Indonesia Branch Office Bengkulu wear or use of accounting information systems as much as 42 employees. Methods of data collection done by survey method, while data analysis using rating scale analysis. The results reveal that the most dominant factor affecting the performance of accounting information systems at Bank Rakyat Indonesia Branch Office Bengkulu end user satisfaction factor is an average of 176, the second factor is the education and training programs by an average of 173 , the next factor is the support of top management an average of 168 and the last factor is the ability of a personal technique average of 165.
\end{abstract}

\section{Key Word: Performance, Accounting Information Systems}

\section{PENDAHULUAN}

Kemajuan teknologi saat ini sangat berpengaruh terhadap kemajuan Sistem Informasi Akuntansi (SIA). Pemanfaatan teknologi tersebut dapat menunjang perusahaan untuk menghasilkan suatu informasi yang cepat, tepat dan akurat. Pengaruh sistem informasi akuntansi sangat besar bagi perusahaan untuk pengambilan keputusan baik bagi pihak internal perusahaan maupun pihak eksternal perusahaan tersebut. Dampak dari kemajuan teknologi itu mendorong perusahaan untuk menggunakan Sistem informasi yang baru yang dapat menghasilkan informasi yang baru dengan memiliki kriteria: dapat dipercaya, tepat serta akurat 
untuk pengambilan keputusan perusahaan. Oleh karena itu perusahaan harus melakukan pengembangan terhadap sistem yang ada. Secara umum pengembangan suatu sistem informasi dilakukan melalui tiga tahap, yaitu: analisis sistem, perancangan sistem, dan implementasi sistem.

Keberhasilan suatu sistem informasi erat kaitannya dengan kinerja yang dimiliki oleh sistem tersebut. Tolak ukur dalam menentukan baik buruknya kinerja sebuah sistem informasi akan dapat dilihat melalui kepuasan dari pemakai sistem informasi akuntansi dan pemakaian dari sistem informasi akuntansi itu sendiri. Kepuasan dari pemakai sistem informasi akuntansi menunjukkan seberapa jauh pemakai merasa senang dan percaya terhadap sistem informasi yang digunakan untuk menghasilkan informasi yang sesuai kebutuhannya (relevan), mengandung sedikit kesalahan (accurate), serta mampu menghasilkan informasi yang tepat waktu (timelines), sedangkan pemakaian sistem informasi akuntansi tingkat keberhasilan sebuah sistem informasi apabila frekuensi penggunaannya sering maka dikatakan baik.

Baik buruknya kinerja Sistem Informasi Akuntansi (SIA) dapat dilihat melalui kepuasan dari pemakai sistem informasi akuntansi itu sendiri dan pemakaian sistem informasi akuntansi. Soegiharto (Sudibyo dan Kuswanto, 2010:2) mengemukakan bahwa ada beberapa faktor yang berpengaruh pada kinerja SIA antara lain: keterlibatan pemakai dalam SIA, kemampuan teknik dari personal SIA, ukuran organisasi, dukungan manajemen puncak, formalisasi pengembangan SIA, program pendidikan dan pelatihan pemakai, keberadaan dewan pengarah sistem informasi, dan lokasi departemen sistem informasi. Keterlibatan pemakai sistem informasi akuntansi yaitu sebagai pengguna atau pemakai sistem tentu sangat penting. Jika sistem yang terkomputerisasi telah memadai sedang user yang terlibat tidak sesuai yang diharapkan tentu merupakan kesia-siaan belaka. Begitu juga dengan kemampuan user yang sangat diharapkan dapat menggunakan sistem dengan optimal, untuk itu maka program pelatihan terhadap pengguna user tentu sangat dibutuhkan sebagai penunjang untuk meningkatkan sistem informasi secara keseluruhan.

Tujuan penelitian yang ingin dicapai dari penelitian ini adalah untuk mengetahui faktor-faktor yang mempengaruhi kinerja sistem informasi akuntansi pada Bank Rakyat Indonesia Kantor Cabang Bengkulu.

\section{TINJAUAN LITERATUR Sistem Informasi Akuntansi}

Susanto (2004:55) mendefinisikan sistem informasi sebagai data yang terorganisir yaitu mengumpulkan, memasukkan, menyimpan, mengelola, mengendalikan serta pelaporan informasi sehingga tujuan organisasi dapat tercapai. Menurut Puspitawati dan Anggadini (2011:64) sistem informasi adalah suatu sistem di dalam suatu organisasi yang mempertemukan kebutuhan pengolahan transaksi harian, mendukung kegiatan operasi seharihari dan menyediakan pihak-pihak tertentu dengan laporan-laporan yang diperlukan.

Sistem informasi, berdasarkan dua definisi di atas secara garis besar adalah sebagai integrasi suatu cara terorganisir mengumpulkan, memasukkan, dan memproses data, mengendalikan,dan menghasilkan informasi dengan berbasis proses manual atau komputer untuk mencapai sasaran dan tujuan organisasi. Sistem informasi mempunyai sebelas komponen yaitu: (1) komponen sasaran dan tujuan, merefleksikan kekuatan pendorong sistem dan alasan keberadaan suatu sistem, (2) komponen input(data), (3) komponen output, informasi untuk pengambilan keputusan, (4) penyimpanan data, (5) pemroses, (6) instruksi dan prosedur, memproses data menjadi informasi, (7) batas sistem, (8) kendala sistem, yaitu keterbatasan intern dan ekstern, (9) komponen pengaman yang berguna dan menjamin informasi yang dihasilkan akurat, (10) komponen interfaceinformasi, berfungsi sebagai penghubung antar pengguna, antara mesin dengan pengguna, antar subsistem dalam sistem informasi, (11) subsistem, merupakan bagian sistem informasi. 
Sedangkan Sistem informasi akuntansi (SIA) merupakan suatu kerangka pengkordinasian sumber daya (data, meterials, equipment, suppliers, personal, andfunds) untuk mengkonversiinput berupa data ekonomik menjadi keluaran berupa informasi keuangan yang digunakan untuk melaksanakan kegiatan suatu entitas dan menyediakan informasi akuntansi bagi pihak-pihak yang berkepentingan (Susanto, 2004:55).

\section{Manfaat Sistem Informasi Akuntansi Bagi Organisasi}

Sistem Informasi akuntansi dapat memberikan manfaat bagi organisasi dengan cara memberikan informasi yang akurat dan tepat waktu agar aktivitas dalam rantai nilai dapat dilaksanakan dengan efektif dan efisien (Romney dan Steinbart, 2006:10). Sistem informasi akuntansi yang dirancang dengan baik dapat melakukan hal ini dengan cara:

a. Memperbaiki kualitas dan mengurangi biaya untuk menghasilkan produk atau jasa.

Sistem informasi akuntansi yang dirancang dengan baik dapat memberikan informasi apabila terdapat proses produksi yang kurang baik atau tidak sesuai dengan standar yang ditetapkan, sehingga dapat segera diperbaiki. Hal ini tentu akan mengurangi biaya untuk perbaikan dalam jumlah yang lebih besar.

b. Memperbaiki efisiensi

Sistem informasi akuntansi yang dirancang dengan baik dapat membantu memperbaiki efisiensi jalannya suatu proses dengan memberikan informasi yang lebih tepat waktu.

c. Memperbaiki pengambilan keputusan

Sistem informasi akuntansi dapat memperbaiki pengambilan keputusan dengan memberikan informasi dengan tepat waktu.

d. Berbagai pengetahuan

Sistem informasi akuntansi yang dirancang dengan baik bisa mempermudah proses berbagai pengetahuan dan keahlian, yang selanjutnya dapat memperbaiki proses operasi perusahaan dan bahkan memberikan keunggulan kompetitif

\section{Faktor-Faktor Yang Mempengaruhi Kinerja Sistem Informasi Akuntansi}

Berikut faktor-faktor yang mempengaruhi kinerja sistem informasi akuntansi menurut Romney dan Steinbart (2006:249-252):

\section{Kemampuan Teknik Personal Sistem Informasi.}

Kemampuan teknis personel SI memiliki pengaruh besar pada analisis informasi persyaratan dan desain sistem informasi. Sebagai contoh, analis sistem yang kompeten memiliki efek positif pada penilaian kebutuhan informasi. Bruwer juga menyarankan bahwa kinerja SI terkait dengan kualitas teknis atau kualitas desain dari sistem, yang merupakan tanggung jawab personil sistem. Kemampuan teknik personal SI dibedakan ke dalam kemampuan spesialis dan kemampuan generalis. Semakin tinggi kemampuan teknik personal SIA akan meningkatkan kinerja SIA dikarenakan adanya hubungan yang positif antara kemampuan teknik personal SIA dengan kinerja SIA.

\section{Dukungan Manajemen Puncak.}

Menurut Romney dan Steinbart (2006:249-252) manajemen puncak adalah manajemen tertinggi yang terdiri dari sekelompok kecil eksekutif. Sering disebut dengan sebutan Presiden Direktur, Wakil Direktur, Wakil Presiden Senior, Kepala Divisi dan lain sebagainya. Dukungan manajemen puncak meliputi jaminan pendanaan dan menentukan prioritas pengembangan. Dukungan dan keterlibatan manajemen puncak memegang penggunaan penting dalam keberhasilan implementasi sistem informasi. Dukungan manajemen puncak tidak hanya penting untuk alokasi sumber daya yang diperlukan, 
melainkan memberikan sinyal yang kuat bagi karyawan bahwa perubahan yang dilakukan merupakan suatu yang penting.

\section{Program Pelatihan dan Pendidikan Pengguna.}

Romney dan Steinbart (2006:249-252) berpendapat bahwa kinerja SIA akan lebih tinggi apabila program pelatihan dan pendidikan pemakai diperkenalkan. Kurangnya pendidikan merupakan alasan utama kurangnya pemanfaatan sistem informasi. Sebuah penelitian tentang keutamaan dari sistem informasi yang dikemukakan oleh Forthe yaitu "pendidikan pengguna" sangat mempengaruhi kinerja sistem informasi akuntansi.

\section{Kepuasan Pengguna Akhir}

Kepuasan Pemakai Sistem Informasi menurut Romney dan Steinbart (2006:249-252) adalah kepuasan pengguna sistem informasi dapat diukur dari kepastian dalam mengembangkan apa yang mereka perlukan. Ketika sebuah sistem informasi diperlukan, penggunaan sistem akan menjadi kurang dan kesuksesan manajemen dengan sistem informasi dapat menentukan kepuasan pengguna akhir.

\section{KERANGKA ANALISIS}

Kerangka analisis dalam penelitian ini dapat dilihat pada gambar berikut ini:

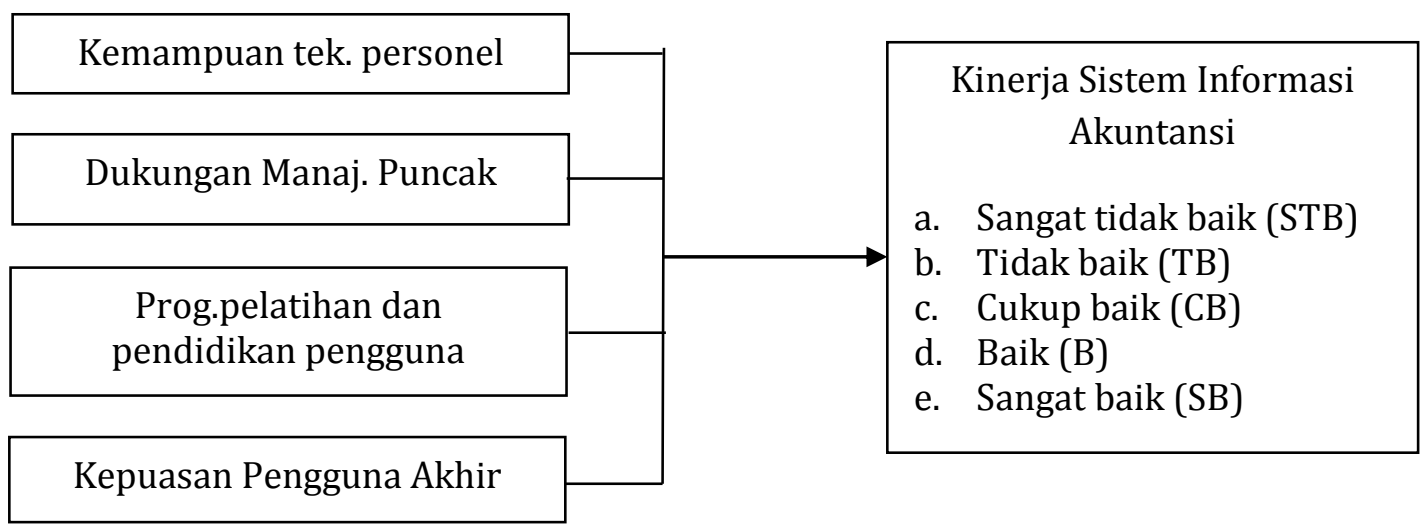

Gambar 1. Kerangka Analisis

\section{HASIL PENELITIAN DAN PEMBAHASAN Analisis RatingScale}

Dari hasil kuesioner yang disebarkan kepada 42 responden karyawan Bank Rakyat Indonesia Kantor Cabang Bengkulu pengguna atau pemakai sistem informasi akuntansi. Hasil dari penyebaran kuesioner untuk faktor yang mempengaruhi kinerja sistem informasi akuntansi meliputi kemampuan teknik personal, dukungan manajemen puncak, program pendidikan dan pelatihan, kepuasan pengguna akhir tersebut adalah sebagai berikut:

a. Tanggapan Responden Terhadap Kemampuan Teknik Personal

Kemampuan teknik personal adalah kesanggupan karyawan pengguna sistem informasi akuntansi di dalam sistem informasi akuntansi yang diterapkan di Bank Rakyat Indonesia Kantor Cabang Bengkulu: 
Tabel 1. Tanggapan Responden Terhadap Kemampuan Teknik Personal

\begin{tabular}{|c|c|c|c|c|c|c|c|}
\hline \multirow{2}{*}{ No } & \multirow{2}{*}{ Pertanyaan } & \multicolumn{5}{|c|}{ Tanggapan } & \multirow{2}{*}{ Skor } \\
\hline & & STB & TB & $\mathrm{CB}$ & B & SB & \\
\hline 1. & $\begin{array}{l}\text { Berdasarkan pengalaman bapak/ibu, staf/pegawai } \\
\text { pada perusahaan telah ditempatkan sesuai dengan } \\
\text { keahliannya pada bidangnya masing-masing }\end{array}$ & 4 & - & 12 & 14 & 12 & 156 \\
\hline 2. & $\begin{array}{l}\text { Berdasarkan pengalaman bapak/ibu, staf/pegawai } \\
\text { pada perusahaan telah mengetahui dan menjalankan } \\
\text { tugas pokok dan fungsinya dengan baik. }\end{array}$ & 1 & 2 & 10 & 13 & 16 & 167 \\
\hline 3. & $\begin{array}{l}\text { Berdasarkan pengalaman bapak/ibu, staf/pegawai } \\
\text { yang bertugas memasukkan data melalui komputer } \\
\text { telah memiliki pemahaman menggunakan komputer. }\end{array}$ & 1 & 1 & 4 & 25 & 11 & 170 \\
\hline 4. & $\begin{array}{l}\text { Berdasarkan pengalaman bapak/ibu, staf/pegawai } \\
\text { yang bertugas memasukkan data menggunakan } \\
\text { komputer telah mendapat pelatihan yang cukup } \\
\text { mengenai bidangnya. }\end{array}$ & - & - & 7 & 28 & 7 & 168 \\
\hline & Rata-Rata & & & & & & 165 \\
\hline
\end{tabular}

Sumber: Hasil Penelitian data diolah, 2015

Berdasarkan tabel 1 di atas dapat diketahui rata-rata tanggapan responden mengenai kemampuan teknik personal yaitu sebesar 165 nilai tersebut berada pada skala penilaian antara 142,9 - 176,4 dengan kriteria penilaian baik. Artinya kemampuan teknik personal pengguna sistem informasi akuntansi pada Bank Rakyat Indonesia Kantor Cabang Bengkulu adalah baik.

Responden penelitian memberikan tanggapan tertinggi sebesar 170 pada pertanyaan nomor tiga yang menyebutkan "staf/pegawai yang bertugas memasukkan data melalui komputer telah memiliki pemahaman menggunakan komputer". Hasil ini mengindikasikan bahwa pengguna sistem informasi akuntansi pada Bank Rakyat Indonesia Kantor Cabang Bengkulu memiliki pemahaman dan kemampuan menggunakan komputer, khususnya mengoperasikan sistem informasi akuntansi perusahaan.

Tanggapan responden terendah sebesar 156 pada pertanyaan nomor 1, pertanyaan ini menyebutkan "staf/pegawai pada perusahaan telah ditempatkan sesuai dengan keahliannya pada bidangnya masing-masing". Hasil ini mengindikasikan bahwa karyawan Bank Rakyat Indonesia Kantor Cabang Bengkulu telah ditempatkan pada posisi jabatan sesuai dengan bidangkeahliannya. Keadaan ini tentu saja dapat mendukung karyawan tersebut dalam memperlancar pekerjaannya, yang pada akhirnya berdampak pada operasional perusahaan.Secara kontinum kemampuan teknik personal pengguna sistem informasi akuntansi dapat dilihat pada gambar 3 berikut:

Gambar 2. Grafik kontinum kemampuan teknik personal

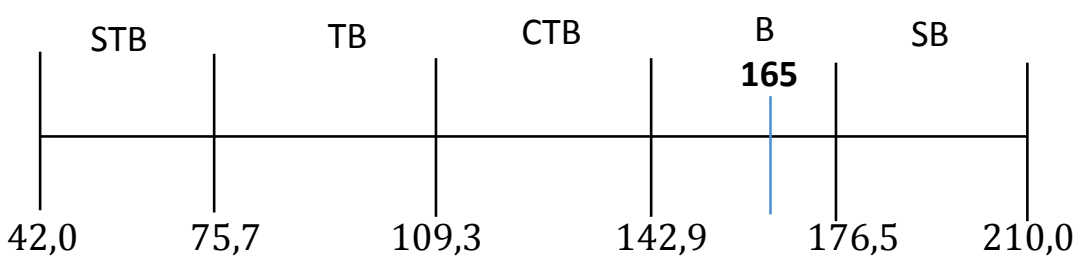

Sumber: Hasil Penelitian data diolah, 2015

Dari gambar 2 di atas menunjukkan bahwa karyawan pengguna atau pemakai sistem informasi akuntansi pada Bank Rakyat Indonesia Kantor Cabang Bengkulu memiliki kemampuan teknik personal yang baik, dimana hasil pengumpulan data sebesar 165 yang terletak pada interval antara 142,9 - 176,4 dengan kriteria penilaian baik. 
b. Tanggapan Responden Terhadap Dukungan Manajemen Puncak

Berikut adalah tanggapan responden mengenai dukungan manajemen puncak terhadap sistem informasi akuntansi perusahaan, khususnya untuk pengguna atau pemakai sistem informasi akuntansi pada Bank Rakyat Indonesia Kantor Cabang Bengkulu:

Tabel 2. Tanggapan Responden Terhadap Dukungan Manajemen Puncak

\begin{tabular}{|c|c|c|c|c|c|c|c|}
\hline \multirow{2}{*}{ No } & \multirow{2}{*}{ Pertanyaan } & \multicolumn{5}{|c|}{ Tanggapan } & \multirow{2}{*}{ Skor } \\
\hline & & STB & TB & CB & B & SB & \\
\hline 1. & $\begin{array}{l}\text { Berdasarkan pengalaman bapak/ibu, pimpinan } \\
\text { berperan dalam penyediaan sistem informasi } \\
\text { akuntansi }\end{array}$ & 2 & 7 & 4 & 10 & 19 & 163 \\
\hline 2. & $\begin{array}{l}\text { Berdasarkan pengalaman bapak/ibu, pimpinan } \\
\text { menyediakan tenaga dan peralatan yang } \\
\text { dibutuhkan dalam menghasilkan sistem } \\
\text { informasi akuntansi }\end{array}$ & 1 & 2 & - & 25 & 14 & 175 \\
\hline 3. & $\begin{array}{l}\text { Berdasarkan pengalaman bapak/ibu, pimpinan } \\
\text { cepat tanggap terhadap permasalahan atau } \\
\text { kendala pada sistem informasi akuntansi }\end{array}$ & 2 & 1 & 7 & 16 & 16 & 169 \\
\hline 4. & $\begin{array}{l}\text { Berdasarkan pengalaman bapak/ibu, pimpinan } \\
\text { memberi dukungan bagi staf/pegawai dalam } \\
\text { kegiatan pelatihan bidang informasi keuangan } \\
\text { perusahaan }\end{array}$ & 1 & 2 & 12 & 13 & 14 & 163 \\
\hline & Rata-Rata & & & & & & 168 \\
\hline
\end{tabular}

Sumber: Hasil Penelitian data diolah, 2015

Berdasarkan tabel 2 di atas dapat diketahui rata-rata tanggapan responden mengenai dukungan manajemen puncak terhadap sistem informasi akuntansi yaitu sebesar 168 nilai tersebut berada pada skala penilaian antara 142,9 - 176,4 dengan kriteria penilaian baik. Artinya manajemen puncak mendukung dengan baik sistem informasi akuntansi pada Bank Rakyat Indonesia Kantor Cabang Bengkulu.

Tanggapan tertinggi mengenai dukungan manajemen puncak adalah sebesar 175 pada pertanyaan nomor dua, pertanyaan ini menyebutkan "pimpinan menyediakan tenaga dan peralatan yang dibutuhkan dalam menghasilkan sistem informasi akuntansi". Hasil ini mengindikasikan bahwa dukungan manajemen puncak terhadap sistem informasi akuntansi pada Bank Rakyat Indonesia Kantor Cabang Bengkulu dengan cara menyediakan peralatan yang modern terutama komputer dan program yang selalu di update.

Tanggapan responden terendah sebesar 163 pada pertanyaan nomor satu dan empat, pertanyaan satu menyebutkan "pimpinan berperan dalam penyediaan sistem informasi akuntansi". Hasil ini mengindikasikan bahwa masih ada beberapa responden yang menyatakan manajemen puncak belum cukup berperan dalam penyediaan informasi akuntansi, tetapi secara keseluruhan responden menyatakan setuju bahwa manajemen puncaklah yang memilik otoritas untuk mengembangkan sistem informasi akuntansi yang lebih baik dan modern. Untuk pertanyaan empat menyebutkan "memberi dukungan bagi staff/pegawai dalam kegiatan pelatihan bidang informasi keuangan perusahaan". Hasil ini mengindikasikan bahwa manajemen puncak memberikan dukungan dengan cara mengadakan kegiatan pelatihan bidang informasi keuangan perusahaan, terutama para karyawan yang berhubungan langsung dengan sistem informasi akuntansi.

Secara kontinum dukungan manajemen puncak terhadap sistem informasi akuntansi dapat dilihat pada gambar 3 berikut: 
Gambar 3. Grafik kontinum dukungan manajemen puncak

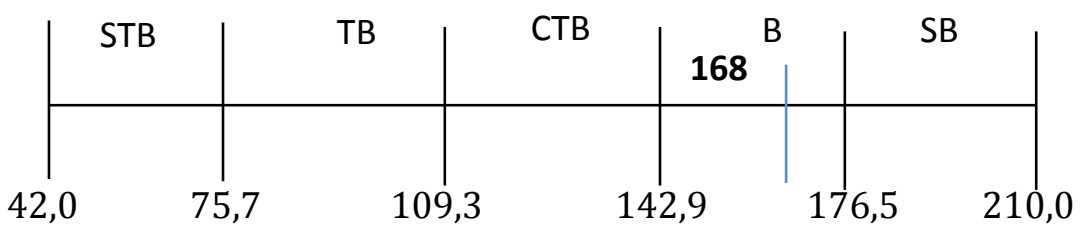

Sumber: Hasil Penelitian data diolah, 2015

Dari gambar 3 di atas menunjukkan bahwa manajemen puncak mendukung sistem informasi akuntansi pada Bank Rakyat Indonesia Kantor Cabang Bengkulu, dimana hasil pengumpulan data sebesar 168 yang terletak pada interval antara 142,9 - 176,4 kriteria penilaian baik.

\section{c. Tanggapan Responden Terhadap Program Pendidikan dan Pelatihan}

Tabel 3. Tanggapan Responden Terhadap Program Pendidikan dan Pelatihan

\begin{tabular}{|c|c|c|c|c|c|c|c|}
\hline \multirow{2}{*}{ No } & \multirow{2}{*}{ Pertanyaan } & \multicolumn{5}{|c|}{ Tanggapan } & \multirow{2}{*}{ Skor } \\
\hline & & STB & TB & $\mathrm{CB}$ & B & SB & \\
\hline 1. & $\begin{array}{l}\text { Berdasarkan pengalaman bapak/ibu, perusahaan } \\
\text { atau departemen memiliki program pelatihan dan } \\
\text { pendidikan }\end{array}$ & - & 1 & 10 & 13 & 18 & 174 \\
\hline 2. & $\begin{array}{l}\text { Berdasarkan pengalaman bapak/ibu, banyak } \\
\text { manfaat yang didapatkan dari program pelatihan } \\
\text { dan pendidikan terutama untuk memudahkan } \\
\text { pekerjaan harian. }\end{array}$ & - & 3 & 1 & 25 & 13 & 174 \\
\hline 3. & $\begin{array}{l}\text { Berdasarkan pengalaman bapak/ibu, tim pengajar } \\
\text { program pelatihan dan pendidikan adalah tenaga } \\
\text { yang sangat ahli di bidangnya. }\end{array}$ & - & - & 6 & 20 & 16 & 178 \\
\hline 4. & $\begin{array}{l}\text { Berdasarkan pengalaman bapak/ibu, staf/pegawai } \\
\text { sangat termotivasi dalam mengikuti program } \\
\text { pelatihan dan pendidikan }\end{array}$ & - & 1 & 10 & 22 & 9 & 165 \\
\hline & Rata-rata & & & & & & 173 \\
\hline
\end{tabular}

Sumber: Hasil Penelitian data diolah, 2015

Berdasarkan tabel 3 di atas dapat diketahui rata-rata tanggapan responden mengenai program pendidikan dan pelatihan pengguna sistem informasi akuntansi yaitu sebesar 173 nilai tersebut berada pada skala penilaian antara 142,9 - 176,4 dengan kriteria penilaian baik. Artinya program pendidikan dan pelatihan pengguna sistem informasi akuntansi pada Bank Rakyat Indonesia Kantor Cabang Bengkulu adalah baik.

Tanggapan tertinggi mengenai program pendidikan pelatihan adalah sebesar 178 pada pertanyaan nomor tiga, pertanyaan ini menyebutkan "tim pengajar program pelatihan dan pendidikan adalah tenaga yang sangat ahli di bidangnya.". Hasil ini mengindikasikan bahwa program pendidikan dan pelatihan yang diikuti pengguna sistem informasi akuntansi pada Bank Rakyat Indonesia Kantor Cabang Bengkulu adalah baik dengan tim pengajar yang sangat ahli dibidangnya.

Tanggapan responden terendah sebesar 165 pada pertanyaan nomor empat, pertanyaan satu menyebutkan "staf/pegawai sangat termotivasi dalam mengikuti program pelatihan dan pendidikan". Hasil ini mengindikasikan bahwa para pegawai masih ingin mengikuti program pendidikan dan pelatihan jika diadakan

Secara kontinum program pendidikan dan pelatihan pengguna sistem informasi akuntansi dapat dilihat pada gambar 4 berikut: 
Gambar 4. Grafik kontinum program pendidikan dan pelatihan

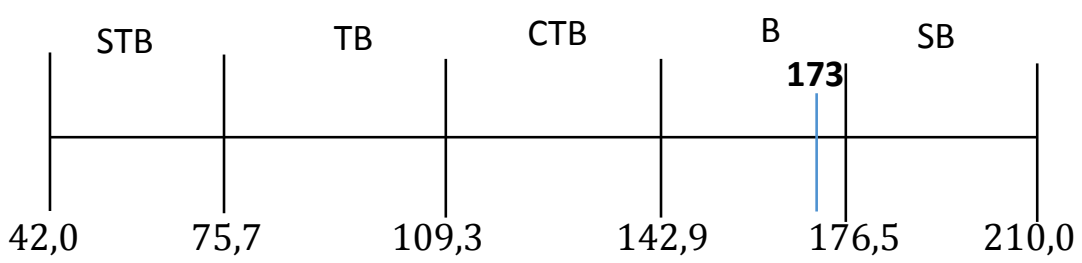

Sumber: Hasil Penelitian data diolah, 2015

Dari gambar 4 di atas menunjukkan bahwa program pendidikan dan pelatihan pengguna sistem informasi akuntansi pada Bank Rakyat Indonesia Kantor Cabang Bengkulu adalah baik, dimana hasil pengumpulan data sebesar 173 yang terletak pada interval antara 142,9 - 176,4 kriteria penilaian baik.

d. Tanggapan Responden Terhadap Kepuasan Pengguna Akhir

Tabel 4. Tanggapan Responden Terhadap Kepuasan Pengguna Akhir

\begin{tabular}{|c|c|c|c|c|c|c|c|}
\hline \multirow{2}{*}{ No } & \multirow{2}{*}{ Pertanyaan } & \multicolumn{5}{|c|}{ Tanggapan } & \multirow{2}{*}{ Skor } \\
\hline & & STB & TB & $\mathrm{CB}$ & B & SB & \\
\hline 1. & $\begin{array}{l}\text { Berdasarkan pengalaman bapak/ibu, } \\
\text { informasi aktem } \\
\text { perusahaan dapat diproses selalu tepat } \\
\text { sesuai dengan yang dibutuhkan perusahaan }\end{array}$ &.- & 1 & 10 & 16 & 16 & 171 \\
\hline 2. & $\begin{array}{l}\text { Berdasarkan pengalaman bapak/ibu, sistem } \\
\text { informasi akuntansi yang digunakan pada } \\
\text { perusahaan dapat menjawab dan menyelesaikan } \\
\text { permasalahan di bidang keuangan sesuai dengan } \\
\text { yang dibutuhkan perusahaan }\end{array}$ & - & - & 3 & 29 & 11 & 175 \\
\hline 3. & $\begin{array}{l}\text { Berdasarkan pengalaman bapak/ibu, } \\
\text { informasi aktem } \\
\text { perusahaan dapat meningkatkan keahlian saya } \\
\text { dalam menangani masalah keuangan perusahaan }\end{array}$ & - & 1 & 3 & 17 & 22 & 184 \\
\hline 4. & $\begin{array}{llr}\text { Berdasarkan pengalaman bapak/ibu, } & \text { sistem } \\
\text { informasi akuntansi yang digunakan } & \text { pada } \\
\text { perusahaan dapat memberikan arah } & \text { bagi } \\
\text { pelaksanaan tugas sehari-hari saya } & & \end{array}$ & - & - & 6 & 23 & 14 & 175 \\
\hline & Rata-rata & & & & & & 176 \\
\hline
\end{tabular}

Sumber: Hasil Penelitian data diolah, 2015

Berdasarkan tabel dapat diketahui rata-rata tanggapan responden kepuasan akhir pengguna sistem informasi akuntansi yaitu sebesar 176 nilai tersebut berada pada skala penilaian antara 142,9 - 176,4 dengan kriteria penilaian baik. Artinya pengguna akhir dari sistem informasi akuntansi pada Bank Rakyat Indonesia Kantor Cabang Bengkulu adalah puas terhadap sistem informasi yang ada di perusahaan.

Tanggapan tertinggi mengenai kepuasan pengguna akhir sistem informasi akuntansi adalah sebesar 184 pada pertanyaan nomor tiga, pertanyaan ini menyebutkan "sistem informasi akuntansi yang digunakan pada perusahaan dapat meningkatkan keahlian saya dalam menangani masalah keuangan perusahaan". Hasil ini mengindikasikan bahwa sistem informasi akuntansi pada Bank Rakyat Indonesia Kantor Cabang Bengkulu bukan saja berdampak terhadap perusahaan, tetapi dapat meningkatkan keahlian pengguna dari sistem informasi akuntansi itu sendiri.

Tanggapan responden terendah sebesar 171 pada pertanyaan nomor satu, pertanyaan satu menyebutkan "sistem informasi akuntansi yang digunakan pada perusahaan dapat 
diproses selalu tepat waktu sesuai dengan yang dibutuhkan perusahaan". Hasil ini mengindikasikan bahwa dengan adanya sistem informasi akuntansi, seluruh kegiatan operasional perusahaan dapat diproses secara tepat waktu.

Secara kontinum kepuasan pengguna akhir sistem informasi akuntansi dapat dilihat pada gambar 5 berikut:

Gambar 5. Grafik kontinum kepuasan akhir pengguna

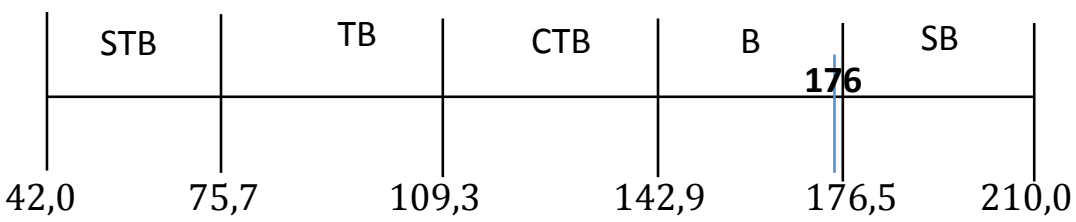

Sumber: Hasil Penelitian data diolah, 2015

Dari gambar 5 di atas menunjukkan bahwa kepuasan pengguna akhir dari sistem informasi akuntansi pada Bank Rakyat Indonesia Kantor Cabang Bengkulu adalah baik, dimana hasil pengumpulan data sebesar 176 yang terletak pada interval antara 142,9 - 176,4 kriteria penilaian baik.

Hasil penelitian terhadap faktor-faktor yang mempengaruhi sistem informasi akuntansi pada Bank Rakyat Indonesia Kantor Cabang Bengkulu, diketahui faktor yang paling dominan berpengaruh dari keempat faktor berdasarkan nilai rata-rata pengumpulan data seperti pada tabel berikut:

Tabel 5. Tanggapan Responden Terhadap Faktor Yang Mempengaruhi Kinerja Sistem Informasi Akuntansi pada BRI Kantor Cabang Bengkulu

\begin{tabular}{|c|l|c|c|}
\hline No & \multicolumn{1}{|c|}{ Faktor } & $\begin{array}{c}\text { Jumlah Rata- } \\
\text { Rata }\end{array}$ & Kriteria \\
\hline 1 & Kepuasan pengguna akhir & 176 & Baik \\
\hline 2 & Program pendidikan dan pelatihan & 173 & Baik \\
\hline 3 & Dukungan manajemen puncak & 168 & Baik \\
\hline 4 & Kemampuan teknik personal & 165 & Baik \\
\hline & Rata-rata & $\mathbf{1 7 0}$ & Baik \\
\hline
\end{tabular}

Sumber: Hasil Penelitian data diolah, 2015

Berdasarkan tabel di atas diketahui bahwa faktor yang paling dominan mempengaruhi sistem informasi akuntansi pada Bank Rakyat Indonesia Kantor Cabang Bengkulu adalah faktor kepuasan pengguna akhir sebesar 176 dengan kriteria baik. Tabel tersebut menunjukkan bahwa pendapat pengguna sistem informasi akuntansi bahwa pengguna memiliki pemahaman mengenai penggunaan komputer terutama dalam menjalankan program sistem informasi akuntansi terutama yang berbasis komputer. Pemahaman dari para pengguna ini dapat berimplikasi dalam kelancaran operasional perusahaan.

Menurut Menurut Romney dan Steinbart (2006:249), kepuasan pemakai sistem adalah respon pemakai terhadap penggunaan keluaran sistem informasi. Kepuasan pengguna sistem informasi merupakan salah satu indikator kesuksesan dari kinerja sistem informasi akuntansi.

Dalam bidang perusahaan perbankan, sistem informasi akuntansi sudah merupakan sebuah sumber daya yang pokok dalam perusahaan. Dalam perusahaan perbankan, pemprosesan akuntansinya sangat rumit dan kompleks mulai dari pembuatan rekening nasabah, penganalisaan transaksi yang terjadi, penjurnalan dan seterusnya sampai pada proses pembuatan informasi akuntansi mengenai seluruh kondisi perusahaan sangat bergantung pada sistem informasi akuntansi yang perusahaan gunakan. Sistem informasi akuntansi yang baik 
akan menghasilkan informasi yang baik pula. Oleh karena itu, pihak bank perlu melakukan evaluasi terhadap sistem informasi akuntansi yang mereka gunakan agar sistem yang sudah mereka pakai selama ini dapat sesuai dengan kebutuhan dan tuntutan kondisi perusahaan khususnya para penggunanya dengan memperhatikan faktor-faktor yang mempengaruhinya.

Pentingnya teknologi informasi bagi keberhasilan organisasi secara keseluruhan memperluas peran fungsi sistem informasi. Pemenuhan kebutuhan pengguna tersebut nantinya akan dapat memberikan kepuasan pada para pengguna jasa sistem informasi dan memotivasi mereka untuk melakukan pekerjaan secara optimal.

Faktor selanjutnya yang mempengaruhi kinerja sistem informasi akuntansi adalah program pendidikan dan pelatihan pengguna. Dengan pelatihan dan pendidikan, pengguna bisa mendapatkan kemampuan untuk mengidentifikasi persyaratan informasi mereka dan kesungguhan serta keterbatasan sistem informasi akuntansi dan kemampuan ini dapat mengarah pada peningkatan kinerja. Menurut Romney dan Steinbart (2006:249) program pendidikan dan pelatihan kepada karyawan sangat dibutuhkan agar karyawan lebih terampil dalam menggunakan sistem yang baru, sehingga program pelatihan dan pendidikan tersebut akan memberikan keuntungan kepada para karyawan dan pengguna sistem dalam menjalankan kegiatan operasional perusahaan. Pengembangan sistem pada umumnya akan lebih baik, jika para anggota tim dilatih sebelumnya. Tentu saja, taraf pelatihan harus disesuaikan dengan pengetahuan setiap anggota. Selain untuk meningkatkan keterampilan teknis, pelatihan berguna untuk memperbaiki komunikasi di kalangan anggota sistem informasi yang baru diimplementasikan, dan biasanya membutuhkan personel baru untuk mengoperasikan dan memeliharanya.

\section{KESIMPULAN}

Berdasarkan hasil penelitian dan pembahasan yang telah dilakukan sebelumnya maka penelitian ini dapat disimpulkan bahwa:

1. Faktor yang paling dominan mempengaruhi kinerja sistem informasi akuntansi pada Bank Rakyat Indonesia Kantor Cabang Bengkulu adalah faktor kepuasan pengguna akhir jumlah rata-rata sebesar 176, terlihat dari pengguna sistem informasi akuntansi memiliki pemahaman mengenai penggunaan komputer dalam mendukung kegiatan perbankan.

2. Faktor kedua adalah program pendidikan dan pelatihan jumlah rata-rata sebesar 173 , dibuktikan dari tim pengajar program pelatihan dan pendidikan adalah tenaga yang sangat ahli di bidangnya.

3. Faktor selanjutnya adalah dukungan manajemen puncak jumlah rata-rata sebesar 168 dibuktikan dari pimpinan bank yang menyediakan peralatan yang dibutuhkan dalam menghasilkan sistem informasi akuntansi

4. Faktor terakhir adalah kemampuan teknik personal jumlah rata-rata sebesar 165, dibuktikan dari sistem informasi akuntansi yang digunakan pada perbankan dapat meningkatkan keahlian pengguna dalam menangani masalah keuangan perusahaan.

\section{SARAN}

Sistem informasi akuntansi yang baik akan menghasilkan informasi yang baik pula. Oleh karena itu, pihak bank perlu melakukan evaluasi terhadap sistem informasi akuntansi yang mereka gunakan agar sistem yang sudah mereka pakai selama ini dapat sesuai dengan kebutuhan dan tuntutan kondisi perusahaan khususnya para penggunanya dengan memperhatikan faktorfaktor yang mempengaruhinya. 


\section{DAFTAR PUSTAKA}

Handoko, T.Hani. 2009. Manajemen Personaliadan Sumber Daya Manusia. Yogyakarta: BPFE UGM.

Jogiyanto HM.2005. Analisis dan Desain Sistem Informasi: Pendekatan Terstruktur Teori dan Praktik Aplikasi Bisnis. Yogyakarta: Andi.

Kadir, Abdul. 2009. Penggunaan System Informasi. Yogyakarta: Andi.

Mulyadi. 2010. Sistem Akuntansi. Salemba Empat, Jakarta.

Puspitawati dan Anggadini. 2011. Sistem Informasi Akuntansi. Yogyakarta: Graha Ilmu.

Romney, B. Marshall dan Paul J. Steinbart. 2006. Sistem Informasi Akuntansi.Jakarta: Salemba Empat. Edisi sembilan.

Soegiharto. 2001. Faktor-Faktor Yang Mempengaruhi Kinerja Sistem Informasi Akuntansi". Gajah Mada International Journal of Business Vol.3 No. 2. [11].

Sugiyono. 2013. Metode Penelitian Kuantitatif Kualitatif dan RD. Bandung: Alfabeta

Sukmadinata, Nana Saodih. 2006. MetodePenelitian Pendidikan, Bandung: Remaja. Rosdakarya

Susanto, Azhar. 2004. Sistem InformasiManajemen, Bandung: Lingga Jaya. 